\title{
Remarkably similar antigen receptors among a subset of patients with chronic lymphocytic leukemia
}

\author{
Fabio Ghiotto, ${ }^{1}$ Franco Fais, ${ }^{1,2}$ Angelo Valetto, ${ }^{1}$ Emilia Albesiano, ${ }^{3}$ Shiori Hashimoto, ${ }^{1}$ \\ Mariella Dono, ${ }^{1}$ Hideyuki Ikematsu, ${ }^{4}$ Steven L. Allen, ${ }^{1,3}$ Jonathan Kolitz,, ${ }^{1,3}$ Kanti R. Rai, ${ }^{3,5}$ \\ Marco Nardini,6 Anna Tramontano,7 Manlio Ferrarini,8 and Nicholas Chiorazzi1,3
}

\begin{abstract}
1Departments of Medicine, North Shore University Hospital and New York University School of Medicine, Manhasset, New York, USA. 2Department of Experimental Medicine, Section of Human Anatomy, University of Genoa, Genoa, Italy. ${ }^{3}$ North Shore-Long Island Jewish Research Institute, Manhasset, New York, USA. ${ }^{4}$ Department of Clinical Research, Hara-Doi Hospital, Higashi-ku, Fukuoka, Japan. ${ }^{5}$ Departments of Medicine, Long Island Jewish Medical Center and Albert Einstein College of Medicine, New Hyde Park, New York, USA. 6 Department of Physics-National Enterprise on Nanoscience and Nanotechnology (INFM) and Center of Excellence in Biomedical Research, University of Genoa, Genoa, Italy. ${ }^{7}$ Department of Biochemical Sciences "Rossi Fanelli," University of Rome "La Sapienza," Rome, Italy. "Division of Medical Oncology C, National Institute for Cancer Research, Genoa, and Department of Clinical and Experimental Oncology, University of Genoa, Genoa, Italy.
\end{abstract}

\begin{abstract}
Studies of B cell antigen receptors (BCRs) expressed by leukemic lymphocytes from patients with B cell chronic lymphocytic leukemia (B-CLL) suggest that B lymphocytes with some level of BCR structural restriction become transformed. While analyzing rearranged $V_{H} D J_{H}$ and $V_{L} J_{L}$ genes of 25 non-IgM-producing B-CLL cases, we found five $\mathrm{IgG}^{+}$cases that display strikingly similar BCRs (use of the same $\mathrm{H}$ - and L-chain $\mathrm{V}$ gene segments with unique, shared heavy chain third complementarity-determining region [HCDR3] and light chain third complementarity-determining region [LCDR3] motifs). These $\mathrm{H}$ - and L-chain characteristics were not identified in other B-CLL cases or in normal B lymphocytes whose sequences are available in the public databases. Three-dimensional modeling studies suggest that these BCRs could bind the same antigenic epitope. The structural features of the B-CLL BCRs resemble those of $\mathrm{mAb}$ 's reactive with carbohydrate determinants of bacterial capsules or viral coats and with certain autoantigens. These findings suggest that the $B$ lymphocytes that gave rise to these $\mathrm{IgG}^{+} \mathrm{B}$-CLL cells were selected for this unique BCR structure. This selection could have occurred because the precursors of the B-CLL cells were chosen for their antigen-binding capabilities by antigen(s) of restricted nature and structure, or because the precursors derived from a $B$ cell subpopulation with limited BCR heterogeneity, or both.
\end{abstract}

\section{Introduction}

B cell chronic lymphocytic leukemia (B-CLL), a monoclonal expansion of mature CD5-expressing B lymphocytes, is a heterogeneous disease that affects primarily individuals over 50 years of age (1). Even though B-CLL is the most common leukemia in the Western hemisphere (2), the events that select out an individual normal $\mathrm{B}$ cell clone and usher it toward leukemic transformation remain unknown. Genetic abnormalities probably exist in these cells and represent important inducers; however, no single unifying molecular genetic defect or combination of defects has yet been identified (3).

Studies of the characteristics of the $\mathrm{B}$ cell antigen receptors (BCRs) expressed by B-CLL cells imply that precursor B lymphocyte clones that eventually become leukemic exhibit varying degrees of BCR structural similarity (4). This restriction in BCR structure suggests that either the precursors of the leukemic B lymphocytes were selected by specific antigens that have affinity

Nonstandard abbreviations used: arsonate (Ars); B cell antigen receptor (BCR); B cell chronic lymphocytic leukemia (B-CLL); double-stranded DNA (dsDNA); framework region (FR); germinal center (GC); heavy chain third complementarity-determining region (HCDR3); light chain third complementarity-determining region (LCDR3); single-stranded DNA (ssDNA); web antibody modeling (WAM).

Conflict of interest: The authors have declared that no conflict of interest exists.

Citation for this article: J. Clin. Invest. 113:1008-1016 (2004).

doi:10.1172/JCI200419399. for these BCRs, or they were garnered from a B cell subpopulation with restricted BCR structural heterogeneity.

In the present study, we analyzed the rearranged $\mathrm{V}_{\mathrm{H}} \mathrm{DJ} \mathrm{J}_{\mathrm{H}}$ and $\mathrm{V}_{\mathrm{L}} \mathrm{J}_{\mathrm{L}}$ genes of a cohort of $25 \mathrm{~B}-\mathrm{CLL}$ patients whose leukemic cells express isotype-switched Ig. Our results reveal that a substantial subset of $\mathrm{IgG}^{+}$cases ( 20\%) display strikingly similar Ig V region gene features. These include the use of the same $\mathrm{H}$ - and $\mathrm{L}$-chain $\mathrm{V}$ gene segments, which are combined in unique ways and exhibit little somatic diversification despite their Ig class-switched nature. These findings are compelling evidence that selection of a specific BCR structure is an important component promoting the development of B-CLL. Preliminary abbreviated reports of these findings have appeared previously $(5,6)$.

\section{Methods}

CLL patients and samples. The Institutional Review Board of North Shore University Hospital (Manhasset, New York) and Long Island Jewish Medical Center (New Hyde Park, New York) approved these studies. From a cohort of 237 patients with clinical and laboratory features of B-CLL, 25 patients with expansions of $\mathrm{CD}^{+} / \mathrm{CD} 19^{+}$ $B$ cells expressing surface membrane IgG or IgA were chosen and analyzed. All of the patients with surface membrane $\operatorname{IgM}^{+}$cells were obtained randomly; some of the $\mathrm{IgG}^{+}$cases were provided by others because of their surface membrane phenotype and therefore were not randomly acquired. Some patients and the $\mathrm{V}$ gene 
sequences of their leukemic cells were described previously (5-9). PBMCs from these patients, obtained from heparinized blood by density gradient centrifugation (Ficoll-Paque; Amersham Biosciences, Piscataway, New Jersey, USA), were used after thawing samples that had been cryopreserved with a programmable cellfreezing machine (CryoMed, Inc., Mt. Clemens, Michigan, USA).

Isolation of DNA. T lymphocytes were purified from PBMCs by negative selection using the Pan T cell isolation kit (Miltenyi Biotec, Auburn, California, USA), and DNA was isolated from these cells with the DNeasy Tissue Kit (QIAGEN Inc., Valencia, California, USA).

Preparation of RNA and synthesis of $c D N A$. Total RNA was isolated from PBMCs using Ultraspec RNA (Biotecx Laboratories Inc., Houston, Texas, USA) according to the manufacturer's instructions. RNA $(1 \mu \mathrm{g})$ was reverse-transcribed to cDNA using $200 \mathrm{U}$ of Moloney murine leukemia virus reverse transcriptase (Invitrogen Corp., Carlsbad, California, USA), 1 U of RNase inhibitor (Eppendorf, Hamburg, Germany), and 20 pmol of oligo dT primer (total volume of $20 \mu \mathrm{l}$ ). These reactants were incubated at $42^{\circ} \mathrm{C}$ for 1 hour, heated at $65^{\circ} \mathrm{C}$ for 10 minutes to stop the reactions, and then diluted to a final volume of $100 \mu \mathrm{l}$.

PCR conditions for IgV gene DNA sequencing. To determine the $\operatorname{Ig} V_{H}$ gene family used by various B-CLL cells, cDNA $(2 \mu \mathrm{l})$ was amplified using sense framework region 1 (FR1) primers specific for the various $\operatorname{Ig} V_{H}$ gene families in conjunction with an appropriate antisense $I g C_{H}$ primer (10). Reactions were carried out in $50 \mu \mathrm{l}$ using 20 pmol of each primer and cycled with a 9600 GeneAmp System (Perkin-Elmer Cetus, Emeryville, California, USA).

The DNA sequence of the B-CLL $\operatorname{Ig} V_{H}$ gene was determined by reamplifying the original cDNA $(2 \mu \mathrm{l})$ using the appropriate $I g V_{H}$ family leader and $I g C_{H}$ primers defined above (10). PCR products were sequenced directly after purification with Wizard PCR Preps (Promega Corp., Madison, Wisconsin, USA) using an automated sequencer (Applied Biosystems, Foster City, California, USA). In some instances where mutations were detected, an independent PCR product was generated and either sequenced directly or cloned into TA vector (Invitrogen Corp.), processed using Wizard minipreps (Promega Corp.), and then sequenced using M13 forward and reverse primers.

To determine $\operatorname{Ig} V_{L}$ gene sequences, cDNA $(2 \mu \mathrm{l})$ was amplified using the leader primers listed in Supplemental Table 1 (supplemental material available at http://www.jci.org/cgi/content/full/113/7/1008/DC1). For the V $\lambda$ families I, III, and IV, a mixture of primers was used. To amplify $V \lambda$ families II and $X$, both forward primers were used in a common reaction, since they cross-prime. Reactions were carried out in a $50-\mu \mathrm{l}$ volume using $20 \mathrm{pmol}$ of each primer, $200 \mu \mathrm{M}$ dNTPs, $1.5 \mathrm{mM}$ $\mathrm{MgCl}_{2}$, and $1.25 \mathrm{U}$ of Taq Gold (Perkin-Elmer), and cycled with a 9600 GeneAmp System as follows: denaturation at $94^{\circ} \mathrm{C}$ for 45 seconds, annealing at $62^{\circ} \mathrm{C}$ for 30 seconds, and extension at $72^{\circ} \mathrm{C}$ for $45 \mathrm{sec}-$ onds. After 35 cycles, extension was continued at $72^{\circ} \mathrm{C}$ for an additional 10 minutes. $\operatorname{Ig} V_{L}$ PCR products were sequenced in the same manner as $\operatorname{Ig} V_{H}$ PCR products.

To identify potential polymorphisms in the germline $V_{H} 4-39$ gene, PCR was performed on DNA from autologous T cells of two patients (nos. 057 and 114) using $V_{H} 4-39$ CDR2-specific gene primers (forward: 5'-GGTGGCGGCTCCCAGATG-3'; reverse: 5' TCACACTCACCTCCCCTCAC-3'). PCR products were cloned and sequenced using the TOPO TA cloning kit (Invitrogen Corp.).

Analyses of $V_{H}, D$, and $J_{H}$ sequences. DNA sequences were compared with those in the V BASE sequence directory (11) using MacVector software, version 6.0 (Accelrys, San Diego, California, USA) as previ- ously described (8). Amino acid sequences were compared with those in GenBank by means of a BLAST search using the tblastn algorithm.

Analyses of heavy chain complementarity region 3 and light chain complementarity region 3 rearrangements. Heavy chain third complementarity-determining region (HCDR3) length was determined according to Kabat and Wu (12) by counting the number of amino acids between position H94 at the $3^{\prime}$ end of FR3 (usually two amino acids downstream of the conserved cysteine) and position $\mathrm{H} 102$ at the beginning of FR4 (a conserved tryptophan in all $\mathrm{J}_{\mathrm{H}}$ segments). Light chain third complementarity-determining region (LCDR3) length was determined by counting amino acids beginning at position L89 (preceded by a conserved cysteine) to position L97 (followed by a conserved Phe-Gly pair). Hypervariable loops were defined according to Chothia and Lesk (13); in particular, the third hypervariable loop of the $\mathrm{H}$ chain $(\mathrm{H} 3)$ spans the amino acids 92-104, in the Kabat et al. numbering scheme (14).

Antibody modeling. Three-dimensional models of the $\mathrm{V}$ domains of the Ig's were constructed using the canonical structure model (14) as implemented in the web antibody modeling (WAM) algorithm (15). Models were analyzed using the molecular graphics package Insight II (16).

\section{Results}

Identification of five IgG-expressing B-CLL cases with remarkably similar $B C R$. While determining $c D N A$ sequences of $\mathrm{V}_{\mathrm{H}} \mathrm{DJ} \mathrm{J}_{\mathrm{H}}$ and $\mathrm{V}_{\mathrm{L}} \mathrm{J}_{\mathrm{L}}$ rearrangements expressed in 25 isotype-switched B-CLL samples (23 $\mathrm{IgG}^{+}$and $2 \mathrm{IgA}^{+}$, see Supplemental Table 2), we identified five IgGexpressing cases with remarkably similar BCRs. These cases (CLL nos. 039, 057, 114, 202, and 209) expressed the same $V_{H}$ [4-39], D [6-13], and $\mathrm{J}_{\mathrm{H}}(5 \mathrm{~b})$ gene segments (Table 1$)$. For the four cases in which L-chain data were obtained (additional sample on CLL no. 209 was not available because the patient died in an automobile

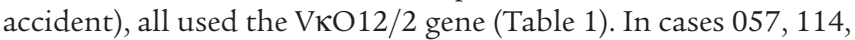
and 202 , this $V_{L}$ gene recombined with the $J \kappa 1$ gene segment; in case no. 039 , the $V \kappa O 12 / 2$ gene was associated with $J \kappa 2$. However, the expressed L chains of these four cases, including CLL no. 039, were virtually identical at the amino acid level (see below).

These five patients had several clinical similarities. The subset comprised primarily women with a 1:4 male/female ratio (Table 1 ), which differs from that in the other isotype-switched cases in this cohort (14:6; see Supplemental Table 2) and in B-CLL cases in general $(\sim 2: 1$ [refs. 1, 2]). Moreover, the patients experienced aggressive clinical courses complicated by severe recurrent infections (no. 039), Richter's transformation (no. 057), or the occurrence of second solid tumors (nos. 114 and 202). There was no familial or consistent ethnic relationship among these cases, and the patients originated from different parts of the world (two from the United States, one from Italy, one from the Caribbean region, and one from Japan).

The majority of the other 20 isotype-switched cases used either a $\mathrm{V}_{\mathrm{H}} 3$ family gene $(50 \%)$ or a $\mathrm{V}_{\mathrm{H}} 4$ family gene (35\%; see Supplemental Table 2). All of these $V_{\mathrm{H}} 4$-expressing cases used the $V_{H} 4-34$ gene. One case (CLL no. 097) used the $V_{L} O 12 / 2$ gene, although this VK gene was mutated and was paired with a mutated $V_{H} 3-73$ gene. Thirteen of the remaining 20 cases expressed $V \kappa$, and six expressed $V \lambda$ genes, with no apparent $V_{L}$ segment biases. All of the $V \gamma$-expressing cases used a $V_{\mathrm{H}} 3$ gene; among these, only $J \lambda 2$ was used.

Ig V gene mutation status. Although the leukemic cells of these five cases synthesized IgG, their $V_{H}$ and $V_{L}$ genes showed minimal deviation from the germline gene sequence $\left(\mathrm{V}_{\mathrm{H}}: 0.3-0.7 \%\right.$, and $\mathrm{V}_{\mathrm{L}}$ 
Table 1

Gene segments expressed by subset of IgG+B-CLL cases

\begin{tabular}{lcccccc} 
CLL no. & Gender & $\begin{array}{c}\text { V gene } \\
\text { family }\end{array}$ & $\begin{array}{c}\text { Most similar } \\
\text { germline } \\
\text { V gene }\end{array}$ & $\begin{array}{c}\text { Percent V gene } \\
\text { difference } \\
\text { from germline }\end{array}$ & D segment & J gene \\
039 & Female & $V_{H} 4$ & $4-39$ & 0.7 & $6-13$ & $5 b$ \\
& & $V_{\kappa 1} 1$ & $012 / 2$ & 0.0 & - & $\kappa 2$ \\
057 & \multirow{2}{*}{ Female } & $V_{H} 4$ & $4-39$ & $0.3^{A}$ & $6-13$ & $5 b$ \\
& & $V_{\kappa 1} 1$ & $012 / 2$ & 0.0 & - & $\kappa 1$ \\
114 & \multirow{2}{*}{ Male } & $V_{H} 4$ & $4-39$ & $0.0^{A}$ & $6-13$ & $5 b$ \\
& & $V_{\kappa 1} 1$ & $012 / 2$ & 0.7 & - & $\kappa 1$ \\
202 & \multirow{2}{*}{ Female } & $V_{H} 4$ & $4-39$ & 0.3 & $6-13$ & $5 b$ \\
& & $V_{\kappa 1} 1$ & $012 / 2$ & 0.0 & - & $\kappa 1$ \\
209 & \multirow{2}{*}{ Female } & $V_{H} 4$ & $4-39$ & 0.3 & $6-13$ & $5 b$ \\
& & $N A$ & $N A$ & $N A$ & $N A$ & $N A$
\end{tabular}

ABased on comparison with patient's genomic (T lymphocyte) germline $V_{H} 4-39$ genes, which differ at one (CLL 057) and three (CLL 114) positions from the canonical germline $V_{H} 4-39$ gene in GenBank. NA, not available.
For $\mathrm{V}_{\mathrm{H}}$, there were only two amino acid changes among the five cases. CLL no. 057 exhibited a Pro $\rightarrow$ Thr change at position H63, and no. 039 displayed an Arg $\rightarrow$ Ser change at position H96; these isolated changes occurred in FR3. The $V_{L}$ protein sequences were also virtually identical; only CLL no. 114 showed a Gln $\rightarrow$ Arg change at position L3 in FR1.

HCDR3 structure. Figure 1A aligns the HCDR3 protein sequences for these five IgG-expressing cases. HCDR3 lengths were very similar (16-17 amino acids). These lengths are longer than most normal B cells (19) and many B-CLL cells $(8,20)$. The HCDR3 sequences of the five cases were very similar, exhibiting a consensus sequence (XXGYSSSWYG/SX(X)NWFDP; Figure 1A) consisting of two N-terminal hydrophilic amino acids, seven invariant amino acids that represent a portion of the $D 6-13$ gene segment read in the hydrophilic reading frame, a glycine or serine that are similar in their small side chains, one to two variable amino acid(s) that lack chemical similarity, and five amino

0.0-0.7\%; Table 1). In contrast, among the other 20 isotypeswitched patients, only four (nos. 040, 097, 158, and 185) expressed both $V_{H}$ and $V_{L}$ genes that differed by $1.0 \%$ or less from the germline counterparts (Supplemental Table 2).

To determine if some of these nucleotide differences represented allelic polymorphisms, we sequenced the $\mathrm{V}_{\mathrm{H}}$ segments from the genomic (T cell) DNA of two patients (nos. 057 and 114; see Supplemental Figure 3). The germline $V_{H} 4-39$ gene sequence for patient no. 057 exhibited one difference from the canonical germline $V_{H} 4-39$ deposited in GenBank, and the germline gene of patient 114 differed at three positions from the GenBank sequence. These findings indicate that some of the nucleotide differences we detected were allelic polymorphisms (Supplemental Figure 3), whereas others were real somatic mutations. A recent communication suggests that most of the $\operatorname{Ig} \mathrm{V}_{\mathrm{H}}$ sequence differences detected in "unmutated" B-CLL cells are somatically attained (17). A lack of somatic mutations in $V_{H} 4-39$ genes from patients with predominantly $\operatorname{IgM}^{+} \mathrm{B}$-CLL has been reported previously $(8,18)$. Supplemental Figure 1, A and B, compares the $V_{H}$ and $V_{L}$ genes of the leukemic cells with the GenBank germline counterpart.

Protein sequences of $\operatorname{Ig} V_{H}$ and $\operatorname{Ig} V_{L}$. Since most of the nucleotide differences in $V_{H}$ and $V_{L}$ were silent, the deduced $V_{H}$ and $V_{L}$ protein sequences of the five $\mathrm{IgG}^{+}$cases were virtually identical to that predicted from their germline genes (Supplemental Figure 2, A and B).

\section{Figure 1}

Amino acid sequences of HCDR3 and LCDR3 of $\operatorname{lgG}+$ B-CLL cases. Amino acid sequences are shown flanked by the $3^{\prime}$ end of FR3 and the $5^{\prime}$ end of FR4. A consensus sequence is shown for each. Color code: identical amino acids are in brown, chemically similar amino acids in blue, unrelated amino acids in black, and differences within areas of identity or similarity in red. (A) HCDR3. The consensus sequence consists of two hydrophilic amino acids (blue), seven amino acids that represent a portion of the germline $D 6-13$ gene segment (brown), a glycine or serine (both with small side chains; brown), one to two variable amino acids, and five amino acids from the $5^{\prime}$ portion of the germline $J_{H} 5 b$ segment. (B) LCDR3. The LCDR3 sequences of all cases are identical, except for a difference in the last amino acid in CLL no. 039, due to the use of the $J_{\kappa} 2$ segment. In each case, an arginine occurs at the $V_{\kappa}-J_{\kappa}$ junction (underlined and in italics). acids corresponding to the $5^{\prime}$ portion of the $J_{H} 5 b$ segment.

$L C D R 3$ structure. The LCDR3 sequences of all cases were identical (Figure 1B), except for a difference in the last amino acid in CLL no. 039 ; this difference results from the use of the $J \kappa 2$ segment in this

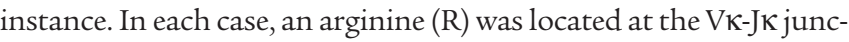
tion (position L96). In CLL no. 114 (Figure 2A), CGG, one of the six possibilities that code for arginine, resulted from coding end trimming and recombination of the $V \kappa$ and $\mathrm{J} \kappa$ germline segments. For cases no. 057 and 202 (Figure 2B), the codon CGA yielded the arginine via a process similar to that for CLL no. 114. However, for CLL no. 039, which used the $J \kappa 2$ gene segment (Figure 2C), the

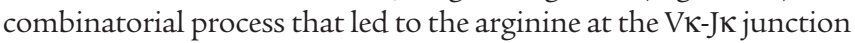
was more complex. This required the trimming of one nucleotide from the $3^{\prime}$ end of $V_{L}$ and the deletion of seven nucleotides from the $5^{\prime}$ end of $J \kappa 2$, along with the nontemplated insertion of two $\mathrm{G}$ nucleotides, to generate an arginine codon (CGG).

Lack of similar rearranged Ig V genes in other human B cells. We searched GenBank for $\mathrm{V}_{\mathrm{H}} \mathrm{DJ}_{\mathrm{H}}$ rearrangements with significant amino acid similarity to the consensus protein sequences of these five B-CLL

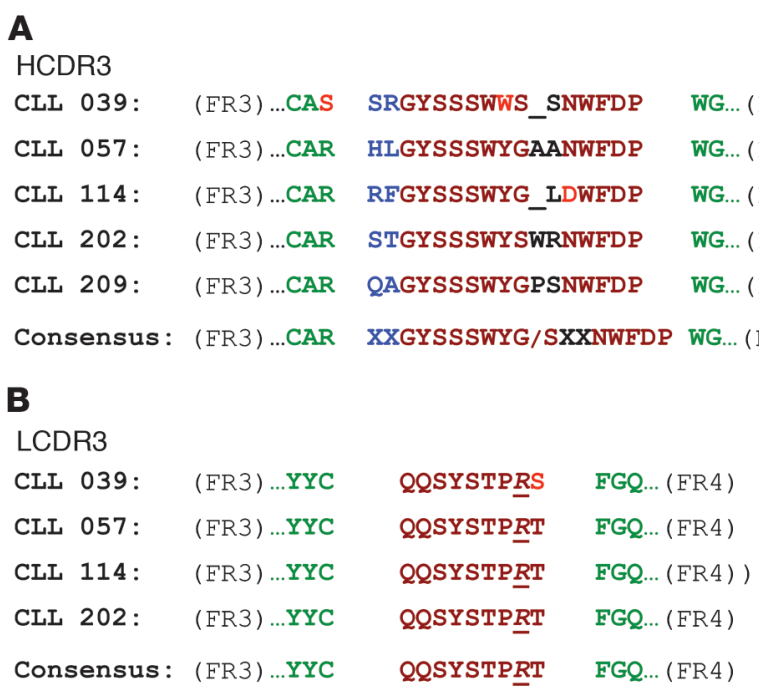




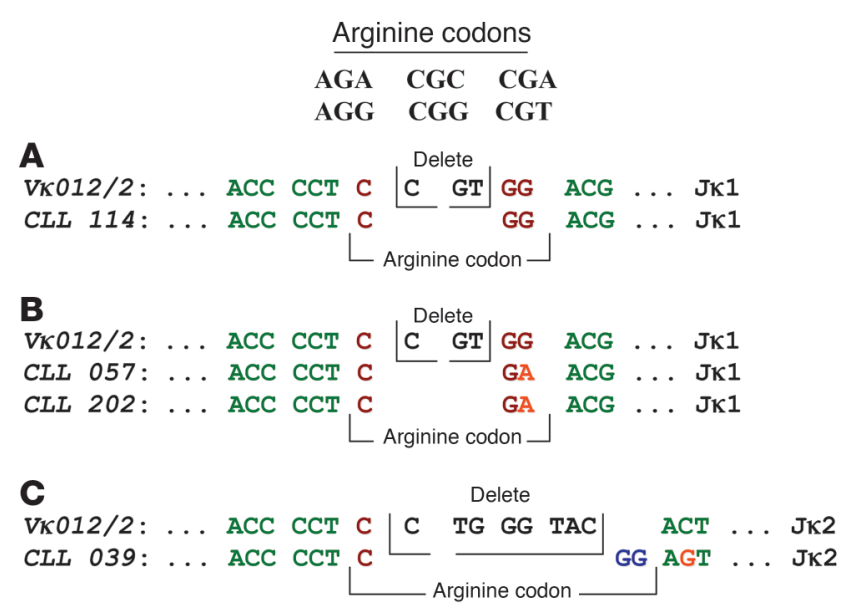

cases. Only one very similar rearrangement was found, and this was from a lymphoplasmacytoid immunocytoma (GenBank entry no. Y09249 [ref. 21]); however, the corresponding L chain in this case was of the $\lambda$ isotype (GenBank entry no. Y09250 [ref. 22]).

We also searched for rearranged $V \kappa O 12 / 2-J \kappa L$ chains of the same LCDR3 length that have an arginine at the $V_{L}-J_{L}$ junction. Because the $\mathrm{V}$ region of an $\mathrm{L}$ chain comprises only two gene segments and because six codons can yield an arginine, the likelihood of identifying rearrangements with similar structure is higher than that for a rearranged $\mathrm{V}_{\mathrm{H}} \mathrm{DJ}$. BLAST search revealed 15 close matches $(100 \%$ to $96.5 \%$ similarity) to the $V \kappa O 12 / 2-\mathrm{J} \kappa$ consensus amino acid sequence of the five $\mathrm{IgG}^{+} \mathrm{B}-\mathrm{CLL}$ cases (Table 2). For 11 of these 15 cases, the companion $\mathrm{V}_{\mathrm{H}} \mathrm{DJ}_{\mathrm{H}}$ segments were available; none of these was $V_{H} 4-39$. Of the $V \kappa O 12 / 2-\mathrm{J} \kappa$ cases with known companion $\mathrm{V}_{\mathrm{H}} \mathrm{DJ}_{\mathrm{H}}$ segments, eight were of defined antigen specificity. Remarkably, of these eight cases, seven were from autoreactive mAb's (anti$\operatorname{IgG}$, anti-RhD, anti-La, anti- $\alpha \operatorname{IIb} \beta 3$ integrin, and antiapoptotic

\section{Figure 2}

Different mechanisms generate an arginine at the $\mathrm{V}_{\mathrm{L}}-\mathrm{J}_{\mathrm{L}}$ junctions. The codons for arginine are listed. Color code: identical nucleotides of the arginine codon are in brown, nucleotides deleted are in black, nucleotides probably resulting from nontemplated nucleotide addition are in dark blue, and differences within areas of identity or similarity in red. (A and $\mathbf{B}$ ) An appropriate codon results from coding end trimming and recombination of the two germline $V \kappa$ and $J \kappa 1$ segments. (C) The arginine codon develops via a more complex combinatorial process, requiring the trimming of one nucleotide from the $3^{\prime}$ end of $\mathrm{V}_{\mathrm{L}}$, the deletion of seven nucleotides from the $5^{\prime}$ end of $J_{K} 2$, and the nontemplated insertion of two $\mathrm{G}$ nucleotides.

cells); the other bound the capsular polysaccharide of Neisseria

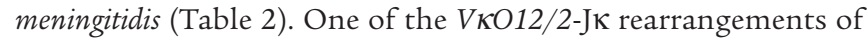
unknown specificity was from a B-CLL clone (GenBank entry no. AF228327); however, this was paired with a $V_{H} 4-34$ gene (GenBank entry no. AF196469 [ref. 23]).

We next searched the Kabat, et al. database (14) and identified 2,950 mAb's for which both $\mathrm{H}$ and $\mathrm{L}$ Ig V genes were known. Among these, we found 199 with an arginine at L96. There was no statistically significant correlation between the presence of an arginine at the $\mathrm{V}_{\mathrm{L}}-\mathrm{J}_{\mathrm{L}}$ junction and a specific, unique antigenic reactivity. However, there was a striking enrichment (102/199) for antibodies that react with structures that serve as autoantigens in several autoimmune settings; examples are double-stranded (ds) and single-stranded (ss) DNA, IgG, and thyroid constituents. This was consistent with the autoreactivity identified in the VKO12/2-JK $\mathrm{V}_{\mathrm{L}}-\mathrm{J}_{\mathrm{L}}$ listed in Table 2.

Three-dimensional models of the B-CLL BCR. We used the canonical structure method (13) as implemented in the WAM algorithm to build models for the $\mathrm{V}$ domains, and then analyzed these structures to deduce characteristics of the antigen-binding sites (Figure 3). The canonical structure model requires that the main chain con-

\section{Table 2}

012/2-JK Gene rearrangements, with similar LCDR3 lengths and junctional arginine (R) from other human B cells

\begin{tabular}{|c|c|c|c|c|}
\hline $\begin{array}{l}\text { GenBank } \\
\text { accession no. }\end{array}$ & $\begin{array}{l}\text { Percent amino acid } \\
\text { difference from } \\
\text { consensus } 012 / 2-\mathrm{JK}^{\mathrm{A}}\end{array}$ & $\mathrm{JK}$ & $V_{H}$ Gene & Source \\
\hline Consensus & - & 1 & $4-39$ & $\lg \mathrm{G}^{+} \mathrm{B}-\mathrm{CLL}$ cases \\
\hline BAC01727 & $0.0 \%$ & 1 & NA & Antibody library from human B cells (Y. Akahori, et al., unpublished data) \\
\hline CAA51109 & $0.0 \%$ & 1 & NA & Phage library using cDNA from human splenic B cells (94) \\
\hline CAD68160 & $0.9 \%(1 \mathrm{AA})$ & 1 & NA & Antibody reactive with apoptotic cells (R. Gandhi, et al., unpublished data) \\
\hline 1HEZA & $0.9 \%(1 \mathrm{AA})$ & 1 & 9.1 & $\kappa$ chain of rheumatoid factor bound by $\kappa$-binding protein (95) \\
\hline AAL65713 & $0.9 \%(1 \mathrm{AA})$ & 2 & $1-46$ & $\begin{array}{l}\text { Hybridoma from human tonsil B lymphocytes (M. Vaisbourd, et al., } \\
\text { unpublished data) }\end{array}$ \\
\hline CAA85588 & $0.9 \%(1 \mathrm{AA})$ & 1 & NA & cDNA library from normal blood B cells (22) \\
\hline CAD43018 & $0.9 \%(2 \mathrm{AA})$ & 4 & $3-21$ & \\
\hline CAD43019 & $1.8 \%(2 \mathrm{AA})$ & 4 & $3-21$ & $\begin{array}{l}\text { Human anti-La autoantibodies from phage display library (J.M.H. Raats, } \\
\text { unpublished data) }\end{array}$ \\
\hline CAD43020 & $1.8 \%(2 \mathrm{AA})$ & 4 & $3-21$ & \\
\hline CAC28926 & $0.9 \%(2 \mathrm{AA})$ & 2 & $1-02$ & Human IgG anti- $\alpha(\mathrm{IIb}) \beta 3$ antibody from phage-displayed library (96) \\
\hline AAD19446 & $1.8 \%(2 \mathrm{AA})$ & 1 & $1-24$ & cDNA library from normal blood B cells (97) \\
\hline 1DEEA & $1.8 \%(2 \mathrm{AA})$ & 1 & $3-30$ & Human monoclonal rheumatoid factor (98) \\
\hline AAN87123 & $1.8 \%(2 \mathrm{AA})$ & 4 & 9.1 & Human IgM antibody to capsular polysaccharide of Neisseria meningitidis (63) \\
\hline AAC13457 & $2.6 \%(3 \mathrm{AA})$ & 4 & $3-33$ & Phage-displayed human anti-Rh(D) antibody (99) \\
\hline AAF86916 & $3.5 \%(4 \mathrm{AA})$ & 2 & $4-34$ & B-CLL cell (23) \\
\hline
\end{tabular}

ADenotes percent and number of amino acid differences from consensus $V_{\kappa} \mathrm{O} 12 / 2-\mathrm{J}_{\kappa}$ sequence of IgG+ $\mathrm{B}-\mathrm{CLL}$ cases. 

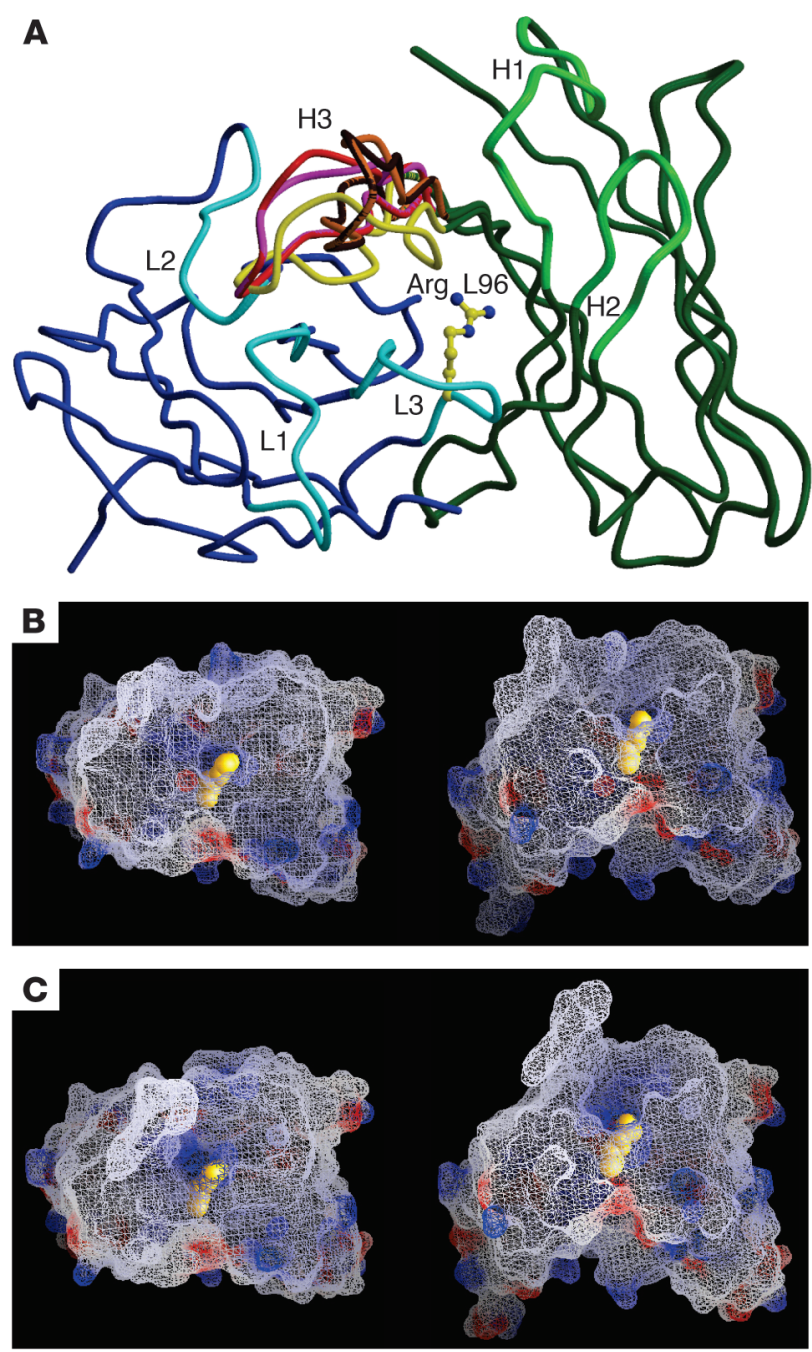

formation of the hypervariable loops depend solely on length and on the nature of a few specific residues. Antibody specificity is therefore determined by the nature of exposed side chains mounted on the main chain of the hypervariable loops, which in turn is determined by their canonical structure.

In the four available B-CLL L chains (case nos. 039, 057, 114, and 202), the L1 loop is six residues long and contains a conserved isoleucine at position 29. In all known antibody structures, sixresidue L1 loops are stabilized by contact of the side chain of this amino acid with residues $2,25,33$, and 71 (13). These contacts determine the main chain structure of the loop. Each of these five residues is hydrophobic and conserved in the four B-CLL rearranged L chains. Since the exposed amino acids of the loop are also conserved, the contribution of this loop to the antigen-binding site would be virtually identical for all four antibodies. The L2 loop has the same conformation in all known $V$ region structures (13). Since there are no substitutions in the exposed side chains of these cases, the contribution of this loop to the binding site is expected to be the same for all the proteins. Similarly, since the backbone structure of the L3 loop depends on its length and the nature of the residues at positions 90 and 95 , which are all identical in the B-CLL sequences, this loop should have the same conformation and solvent-exposed surface in all four cases.

\section{Figure 3}

C-alpha trace of the structural models produced by WAM. (A) Overlay of main chains of the five CLL three-dimensional structures. For CLL no. 209 , the consensus L-chain amino acid sequence was added for WAM analysis. B-CLL L chains are shown in blue color (hypervariable loops L1, L2, and L3 in light blue), and $\mathrm{H}$ chains are shown in green color (hypervariable loops $\mathrm{H} 1$, and $\mathrm{H} 2$ in light green). The different $\mathrm{H} 3$ loop structures are color-coded, as noted by the lime green, red, black, purple, and dark green lines in the $\mathrm{H} 3$ area. Figure was prepared with MOLSCRIPT (91), and Raster3D (92). (B and C) Electrostatic and molecular surface representation of the structure of CLL no. 039 as a model representative of the B-CLL cases of nonbulged conformation (nos. 039 and 114; B) and of the CLL no. 057 as a model of the cases of bulged conformation (nos. 057, 202, and 209; C). Negative surface potentials are indicated in red, positive surface potentials in blue, and neutral potentials in white. The arginine L96 side chain is shown in yellow CPK representation. The structures are shown from a top view (left panels) and from a side view, corresponding to an approximately $70^{\circ}$ rotation relative to the top view (right panels). Figures were prepared with GRASP (93). Arg L96; arginine L96 side chain.

The H1 loop has a conserved hydrophobic residue in position 29 and a conserved glycine in position 26 . The former establishes stabilizing interactions with residues 34,72 , and 77 . Each of these five residues is conserved among the $\mathrm{V}_{\mathrm{H}}$ sequences of the five $\mathrm{B}-\mathrm{CLL}$ cases. Consistent with these observations, the WAM prediction server produces identical models in this region for the five antibodies. The $\mathrm{H} 2$ conformation has been shown to depend only on its length and on the residue at position 71 (24); both of these features are conserved in the five B-CLL sequences.

One cannot infer as clear a sequence-structure relationship for $\mathrm{H} 3$, since this loop is the most variable in length and sequence. The conformation of $\mathrm{H} 3$ is mainly determined by the presence or absence of a $\beta$ bulge within its structure, in the region closer to the FR. The presence of a $\beta$ bulge is in turn determined by the amino acid sequence of the loop (25). Based on our modeling analyses, the $\mathrm{H} 3$ loop is predicted not to be bulged in CLL nos. 039 and 114 and bulged at residue H101 in CLL nos. 057, 202, and 209. The creation of the bulge in the latter cases implies that residue $\mathrm{H} 101 \mathrm{~m}$ of the nonbulged loops is in a position equivalent to that of residue H101 of the bulged loops. Thus, the tip of the loop probably contains the same number of residues $(n=14)$ in all cases, and the residues in the bulged cases can maintain a relationship in space similar to that of the non-bulged cases.

\section{Discussion}

In this study we describe five IgG-expressing B-CLL cases with remarkably similar BCRs. These receptors consist of the same $V_{H}$, $\mathrm{D}, \mathrm{J}_{\mathrm{H}}$, and $\mathrm{V}_{\mathrm{L}}, \mathrm{J}_{\mathrm{L}}$ gene segments, except for a different $\mathrm{J} \kappa$ segment in one instance. Despite this difference, all BCRs have identical LCDR3s and very similar HCDR3s, each with unique sequence and junctional motifs. This BCR restriction could be the consequence of either random transformation of a subpopulation of B cells with very limited antigen receptor heterogeneity - determined genetically or by antigen selection; or specific transformation of B cells that were selected by antigen from a BCR-restricted or BCR-heterogeneous subpopulation; or both. Whatever the cause, our findings support the concept that B-CLL develops from a limited set of B lymphocytes of defined BCR structure and imply that selection of B cells with such structures represents an important promoting influence in the evolution of the leukemic cells. 
Composition, motifs, and three-dimensional structure models. Developing B lymphocytes do not use all germline $\operatorname{IgV}$ gene segments with the same frequency, and biases in gene segment rearrangement do occur (26-29). Nevertheless, considering combinatorial diversity, imprecise joining, nucleotide insertion and deletion, and somatic hypermutation, the probability of finding selectively in one disease, by chance alone, five cell clones with such highly similar rearranged $\mathrm{H}$ - and L-chain $\mathrm{V}$ region pairs is extremely low. The probability that specific $V_{H}, D$, and $J_{H}$ genes would be used in the same $V_{H} D J_{H}$ rearrangement is 1 in $7,128(1 / 44 \times 1 / 27 \times 1 / 6)$; for a specific $V_{L}$ and $J_{L}$ gene pair the probability is $1 / 230(1 / 46 \times 1 / 5)$ or $1 / 252(1 / 36 \times 1 / 7)$ for a $\kappa$ versus a $\lambda$ rearrangement, respectively. Only 1 in $1,639,440$ $B$ cells would be predicted to randomly express the same $V_{H}, D, J_{H}$, $V \kappa$, and $\mathrm{J} \kappa$ segments in its BCR. These calculations use the number of germline $V$ segments in IgBLAST and assume that $\kappa$ genes rearrange before $\lambda$ genes.

Considering these estimations, the frequency at which this BCR occurs in our IgG $\mathrm{G}^{+} \mathrm{B}-\mathrm{CLL}$ cases is extraordinary ( 20\%). Although this percentage will need confirmation, the frequency of such unique $\mathrm{IgG}^{+}$cases is very similar to that identified when we first reported on $\mathrm{IgV}$ gene diversification and apparent antigen selection in a smaller number of isotype-switched B-CLL cases (7). This structure was not seen in our IgM ${ }^{+}$B-CLL cohort ( $>175$ cases for which both the rearranged $\mathrm{V}_{\mathrm{H}} \mathrm{DJ} \mathrm{J}_{\mathrm{H}}$ and $\mathrm{V}_{\mathrm{L}} \mathrm{J}_{\mathrm{L}}$ are known) or in GenBank, indicating that this BCR is not overexpressed among $\operatorname{IgM}^{+} \mathrm{B}-\mathrm{CLL}$ cases or in the normal circulating $B$ cell repertoire. We cannot rule out that its frequency increases with age or that it exists among certain distinct noncirculating subpopulations of B cells, although a recent study suggests that the former may be unlikely (30).

Notwithstanding the present limitations of antibody modeling, primarily with respect to the $\mathrm{H} 3$ loop, we can reliably conclude that most of the binding site is identical among these $\operatorname{IgG}^{+} \mathrm{B}-\mathrm{CLL}$ cases. Five of the six $\mathrm{H}$ and $\mathrm{L}$ loops have the same main chain conformation and differ, in only one case, by a conservative Ser $\rightarrow$ Thr side chain change at position 97 of the L chain. However, this residue does not contact antigen in any known structure (Veronica Morea, personal communication). The $\mathrm{H} 3$ loops are also quite similar among the five antibodies, although three are longer by one residue (Figure 1). Since these loops contain a bulge (i.e., they have one residue that is extruded from the regular $\beta$ structure), the residues at the central region of the loop, which are more relevant for antigen binding, can maintain the same relationship in space in all five cases. Therefore, the antigen-binding surfaces of these antibodies are probably very similar, and they likely bind the same antigenic epitope. Nevertheless since some amino acid differences do exist at the $V_{H^{-}} D$ and $\mathrm{D}-\mathrm{J}_{\mathrm{H}}$ junctions, this remains conjecture.

Restricted IgV gene structural features of antibodies with defined antigenic reactivities. Normal and neoplastic $B$ cells of known antigen specificity can display restricted V (D), J segment use, either at both $\mathrm{H}$ and L chain loci or individually at either locus. Murine mAb's reactive with $\beta$-(1,6)-D-galactan $(31), \alpha(1 \rightarrow 6)$ dextran $(32,33)$, phosphorylcholine (34), dextrans and fructofurans (35), and phosphatidylcholine (36-38) pair very restricted and characteristic $\mathrm{V}_{\mathrm{H}} \mathrm{DJ}_{\mathrm{H}}$ and $\mathrm{V}_{\mathrm{L}} \mathrm{J}_{\mathrm{L}}$ gene segments. Human antibodies that exhibit individual $\mathrm{H}$ - or $\mathrm{L}$-chain restrictions include $\mathrm{mAb}$ 's specific for the capsular polysaccharides of Haemophilus influenzae type b (39-41) and Streptococcus pneumoniae $(42,43)$ (individual $\mathrm{V}_{\mathrm{H}} 3$ genes for both), monoclonal cold agglutinins with anti-I specificity (exclusively $\mathrm{V}_{\mathrm{H}} 4-34$ [refs. 44-46]), and monoclonal rheumatoid factors with IgG reactivity $\left(\mathrm{V}_{\mathrm{H}} 1-69\right.$ [refs. 47-51]). Murine anti-arsonate (52-54) and anti-bacterial polysaccharide mAb's (55) frequently use specific individual $V \kappa$ and $\mathrm{J} \kappa$ genes.

In addition, mAb's reactive with carbohydrates $(30,32,40,56)$, autoantigens $(57,58)$, and haptens $(52-54)$ often have characteristic $\mathrm{V}_{\mathrm{L}}-\mathrm{J}_{\mathrm{L}}$ junctional residues. Human anti-H. influenzae mAb's that use the VKA2 gene segment contain an arginine at position L96, although chain recombination experiments suggest that it is not essential for antigen binding $(40,56)$. Murine mAb's reactive with arsonate (Ars), dsDNA, and $\beta-(1,6)$-D-galactan exhibit an arginine or an isoleucine at position L96, respectively. These junctional amino acids are essential for binding to Ars (53), but not to $\beta-(1,6)$-D-galactan (59).

Nature of the antigen that could have selected these BCRs. Our findings suggest that the $\mathrm{B}$ lymphocytes that gave rise to these $\mathrm{IgG}^{+} \mathrm{B}-\mathrm{CLL}$ cells were selected for a unique BCR structure. If this selection involved antigen binding and triggering through the BCR, the antigen(s) would most likely have been of restricted nature and structure. Although the identity of such an antigen is unknown, we can infer certain features based on our data.

First, the diverse geographic origins of our patients suggests that the putative structure would probably be distributed worldwide. Second, the epitope would appear to select out and drive B cells to undergo an isotype class switch, since we found this BCR only in non-IgM-expressing B-CLL cells. Third, this selection and drive would not frequently lead to clonal expansion of normal B cells, since we could not identify this BCR in B lymphocytes from normal individuals deposited in GenBank. Fourth, the presence of a positively charged center to the antigen-binding pocket, provided by the side chain of arginine L96, and surrounded by an aromatic area and a ridge of polar residues, would imply that a negatively charged or electron-rich group exists in the epitope interactive with these BCRs (Figure 3). This, however, is not a necessity $(41,53,59)$. Of the 199 completely sequenced antibodies with an arginine at L96 (14), we found that about 50\% react with autoantigens. This is consistent with the association with autoreactivity in the VКO12/ 2-JK rearrangements listed in Table 2. Autoantigens can be negatively charged molecules (e.g., DNA), and their reactivity with positively charged residues in the CDRs of autoantibodies is enhanced as the number of these latter residues increases $(58,60)$. Finally, in light of the comparisons with antibodies of known specificities, the epitope could be a carbohydrate that is restricted to a unique molecule or shared by several molecules, an autoantigen that is shared by all individuals or polymorphic among populations, or a carbohydrate determinant of an autoantigen. The possibility that two classes of antigens can bind to the same binding site also should not be ruled out (61).

It is of interest that several relationships exist between carbohydrate reactivity and autoreactivity. Autoantibodies can react with carbohydrates (62-65) and can confer protection against infection with encapsulated bacteria $(66,67)$. In addition, antipneumococcal polysaccharide antibodies can convert to anti-dsDNA reactivity after minimal amino acid changes in the $\mathrm{Ig} \mathrm{V}$ region (68). In this regard, it is known that the BCRs of B-CLL clones can be autoreactive $(69,70)$ and can express cross-reactive idiotypes of dsDNA antibodies (71).

Importance of B cell precursors with constrained BCR structural diversity in the development and progression of B-CLL. Irrespective of the nature of the antigen(s) possibly involved in these cases, these five $\mathrm{IgG}^{+}$clones are extraordinary examples of the principle that B-CLL progenitors are selected for certain limited BCR structures (4). Sim- 
ilar evidence for BCR restriction, possibly attained by antigen or superantigen selection, can be found among the IgM-expressing cases that use a $V_{H} 3-21$ gene with a restricted $V \lambda$ partner $(72,73)$, and probably in those cases that use an unmutated $V_{H} 1-69$ gene with a characteristic $\operatorname{HCDR} 3(8,20)$.

Although the expression of BCRs of class-switched isotype often suggest involvement in $\mathrm{T}$ cell-dependent responses, the lack of significant numbers of $\operatorname{IgV}$ gene mutations in B lymphocytes is unusual for $T$ cell-mediated differentiation and classical germinal center (GC) passage, unless one invokes the possibilities that the germline sequence is preferred for antigen binding or that secondary rearrangements occurred at both the $\mathrm{H}$ - and L-chain loci. However, the lack of $\operatorname{IgV}$ gene mutations and the occurrence of a limited degree of isotype class switching also occur during B cell clonal expansion in the absence of $\mathrm{T}$ cell help and in response to T-independent antigens (74). Previous studies suggest that antigen-stimulated B cells that participate in a $\mathrm{GC}$ reaction lead to $\mathrm{B}$ cell lymphoproliferative disorders such as follicular cell lymphoma and Burkitt's lymphoma (75). Nevertheless, B cells that follow a different pathway of B cell activation - that is, one not involving a classical GC reaction (76, 77 ) - could develop into B-CLL cells in certain instances. The marginal zone is considered a possible site for such nonclassical GC reactions (74) and the development of B-CLL from marginal zone $\mathrm{B}$ cells has been suggested (4). This suggestion is intriguing because the marginal zone is enriched in B cells that react with carbohydrates (74) and autoantigens (78-80), and its Ig V gene repertoire, at least in rodents, is highly restricted $(81,82)$. This receptor restriction apparently occurs early in life and is based on BCR composition, specificity, and signal-transducing capacity (81).

Finally, since these and other B-CLL clones express BCRs with restricted antigen-binding sites, antigen drive could promote intraclonal evolution leading to accumulation of deleterious DNA mutations by members of the leukemic clone and subsequently to a more aggressive clinical course. Repetitive engagement of the BCRs by either autoantigens or foreign antigens, possibly from microorganisms that are encountered during intermittent or persistent infections, could elicit such effects. In this regard, the cases that have the most convincing molecular evidence for $\mathrm{BCR}$ restriction and antigen or superantigen selection (i.e., these $\mathrm{IgG}^{+}$cases and those expressing $V_{H} 3-21$ and $\left.V_{H} 1-69\right)$ experience more aggressive clinical courses with shortened mean survival times $(72,83$, 84). In addition, ongoing $B$ cell activation and differentiation can occur in B-CLL cells $(10,85-88)$ and may be initiated or augmented by BCR-mediated signal transduction that is preserved more often in those cases with the worst clinical outcomes $(89,90)$.

\section{Acknowledgments}

The authors appreciate the valuable discussions and suggestions of Martin Weigert (Princeton University) and Michael Potter (National Cancer Institute). These studies were supported in part by RO1 grants from the National Cancer Institute (CA 81554 and CA 87956), General Clinical Research Center grant (M01 RR018535) from the NIH/NCRR, the Joseph Eletto Leukemia Research Fund, the Jean Walton Fund for Lymphoma and Myeloma Research, the Peter Jay Sharp Foundation, and Associazone Italiana Ricerca sul Cancro (AIRC).

Received for publication July 3, 2003, and accepted in revised form January 6, 2004.

Address correspondence to: Nicholas Chiorazzi, North Shore-LIJ Research Institute, 350 Community Drive, Manhasset, New York 11030, USA. Phone: (516) 562-1085; Fax: (516) 562-1022; E-mail: nchizzi@nshs.edu.

Fabio Ghiotto's present address is: Dipartimento di Medicina Sperimentale, Sezione di Anatomia Umana, Università di Genova, Genoa, Italy.

Angelo Valetto's present address is: Divisione di Citogenetica e Genetica Molecolare, Azienda Ospedaliera Pisana Santa Chiara, Pisa, Italy.

Shiori Hashimoto's present address is: Department of Neurology, Neurological Institute, Tokyo Women's Medical University, Tokyo, Japan.

Mariella Dono's present address is: Division of Medical Oncology C, Istituto Nazionale per la Ricerca sul Cancro, Genoa, Italy.
1. Rai, K.R., and Patel, D.V. 1995. Chronic lymphocytic leukemia. In Hematology: basic principles and practice. R. Hoffman, E. Benz, S. Shattil, B. Furie, H. Cohen, and L. Silberstein, editors. Churchill Livingstone, New York. 1308-1321.

2. Rozman, C., and Montserrat, E. 1995. Chronic lymphocytic leukemia. N. Engl. J. Med. 333:1052-1057.

3. Oscier, D.G. 1994. Cytogenetic and molecular abnormalities in chronic lymphocytic leukaemia. Blood Rev. 8:88-97.

4. Chiorazzi, N., and Ferrarini, M. 2003. B cell chronic lymphocytic leukemia: lessons learned from studies of the B cell antigen receptor. Ann. Rev. Immunol. 21:841-894.

5. Valetto, A., et al. 1998. A subset of $\mathrm{IgG}^{+}$B-CLL cells expresses virtually identical antigens receptors that bind similar peptides. Blood. 92:431a.

6. Chiorazzi, N., and Ferrarini, M. 2001. Immunoglobulin variable region gene characteristics and surface membrane phenotype define B-CLL subgroups with distinct clinical courses. In Chronic lymphoid leukemia, $2^{\text {nd }}$ Ed. B.D. Cheson, editor. Marcel Dekker, New York. 81-109.

7. Hashimoto, S., et al. 1995. Somatic diversification and selection of immunoglobulin heavy and light chain variable region genes in $\mathrm{IgG}^{+} \mathrm{CD}^{+}$chronic lymphocytic leukemia B cells. J. Exp. Med. 181:1507-1517.

8. Fais, F., et al. 1998. Chronic lymphocytic leukemia B cells express restricted sets of mutated and unmutated antigen receptors. J. Clin. Invest. 102:1515-1525.

9. Ikematsu, W., et al. 1994. Surface phenotype and Ig heavy-chain gene usage in chronic B-cell leukemias: expression of myelomonocytic surface markers in CD5- chronic B-cell leukemia. Blood. 83:2602-2610.

10. Fais, F., et al. 1996. Examples of in vivo isotype class switching in $\mathrm{IgM}^{+}$chronic lymphocytic leukemia B cells. J. Clin. Invest. 98:1659-1666.

11. Tomlinson, I., Williams, S., Corbett, S., Cox, J., and Winter, G. 1996. V BASE sequence directory. MRC Centre for Protein Engineering, Cambridge, United Kingdom. http://www.mrc-cpe.cam.ac.uk/vbaseok.php?menu=901.

12. Kabat, E.A., Wu, T.T., Perry, H.M., Gottesman, K.S., and Foeller, C. 1991. Sequences of proteins of immunological interest. Public Health Service, National Institutes of Health, Washington, DC.

13. Chothia, C., and Lesk, A.M. 1987. Canonical structures for the hypervariable regions of immunoglobulins. J. Mol. Biol. 196:901-917.

14. Johnson, G., and Wu, T.T. 2000. Kabat database and its applications: 30 years after the first variability plot. Nucleic Acids Res. 28:214-218.

15. Web Antibody Modelling. http://www.bath.ac.uk/ cpad/.

16. Dayringer, H.E., Tramontano, A., Sprang, S.R., and Fletterick, R.J. 1986. Interactive program for visualization and modeling of protein, nucleic acid and small molecules. J. Mol. Graph. 4:82-87.

17. Davis, Z.A., Orchard, J.A., Corcoran, M.M., and Oscier, D.G. 2003. Divergence from the germ-line sequence in unmutated chronic lymphocytic leukemia is due to somatic mutation rather than polymorphisms. Blood. 102:3075.

18. Schroeder, H.W., Jr., and Dighiero, G. 1994. The pathogenesis of chronic lymphocytic leukemia: analysis of the antibody repertoire. Immunol. Today. 15:288-294.

19. Brezinschek, H.P., et al. 1997. Analysis of the human $V_{H}$ gene repertoire. Differential effects of selection and somatic hypermutation on human peripheral $\mathrm{CD}^{(+)} / \mathrm{IgM}^{+}$and $\mathrm{CD}^{(-)} / \operatorname{IgM}^{+} \mathrm{B}$ cells. J. Clin. Invest. 99:2488-2501.

20. Johnson, T.A., Rassenti, L.Z., and Kipps, T.J. 1997. Ig $V_{\mathrm{H}} 1$ genes expressed in B cell chronic lymphocytic leukemia exhibit distinctive molecular features. J. Immunol. 158:235-246.

21. Terness, P., et al. 1997. Idiotypic vaccine for treat- 
ment of human B-cell lymphoma. Construction of IgG variable regions from single malignant B cells. Hum. Immunol. 56:17-27.

22. Welschof, M., et al. 1995. Amino acid sequence based PCR primers for amplification of rearranged human heavy and light chain immunoglobulin variable region genes. J. Immunol. Methods. 179:203-214.

23. Maloum, K., et al. 2000. Expression of unmutated $\mathrm{V}_{\mathrm{H}}$ genes is a detrimental prognostic factor in chronic lymphocytic leukemia. Blood. 96:377-379.

24. Tramontano, A., Chothia, C., and Lesk, A.M. 1990. Framework residue 71 is a major determinant of the position and conformation of the second hypervariable region in the $\mathrm{V}_{\mathrm{H}}$ domains of immunoglobulins. J. Mol. Biol. 215:175-182.

25. Morea, V., Tramontano, A., Rustici, M., Chothia, C., and Lesk, A.M. 1998. Conformations of the third hypervariable region in the $\mathrm{V}_{\mathrm{H}}$ domain of immunoglobulins. J. Mol. Biol. 275:269-294.

26. Albesiano, E., et al. 2003. Multiple examples of identical heavy and light chain Ig rearrangements support a primary role for antigen in the development of B-CLL. Blood. 102:664a.

27. Tobin, $G$., et al. 2003. Restricted $V_{H}, D$ and $J_{H}$ gene usage and homologous CDR3s in chronic lymphocytic leukemia (CLL). Blood. In press.

28. Feeney, A.J. 1992. Predominance of $\mathrm{V}_{\mathrm{H}}-\mathrm{D}-\mathrm{J}_{\mathrm{H}}$ junctions occurring at sites of short sequence homology results in limited junctional diversity in neonatal antibodies. J. Immunol. 149:222-229.

29. Gu, H., Forster, I., and Rajewsky, K. 1990. Sequence homologies, $\mathrm{N}$ sequence insertion and $\mathrm{J}_{\mathrm{H}}$ gene utilization in $\mathrm{V}_{\mathrm{H}} \mathrm{DJ} \mathrm{H}_{\mathrm{H}}$ joining: implications for the joining mechanism and the ontogenetic timing of Ly1 $\mathrm{B}$ cell and B-CLL progenitor generation. EMBO J. 9:2133-2140.

30. Potter, K.N., et al. 2003. Features of the overexpressed V1-69 genes in the unmutated subset of chronic lymphocytic leukemia are distinct from those in the healthy elderly repertoire. Blood. 101:3082-3084.

31. Rudikoff, S. 1988. Antibodies to beta(1,6)-D-galactan: proteins, idiotypes and genes. Immunol. Rev. 105:97-111.

32. Sikder, S.K., Akolkar, P.N., Kaladas, P.M., Morrison, S.L., and Kabat, E.A. 1985. Sequences of variable regions of hybridoma antibodies to alpha (1--6) dextran in BALB/c and C57BL/ 6 mice. J. Immunol. 135:4215-4221.

33. Wang, D.N., et al. 1990. Two families of monoclonal antibodies to alpha(1--6)dextran, $\mathrm{V}_{\mathrm{H}} 19.1 .2$ and $\mathrm{V}_{\mathrm{H}} 9.14 .7$, show distinct patterns of $\mathrm{J}$ kappa and $\mathrm{J}_{\mathrm{H}}$ minigene usage and amino acid substitutions in CDR3. J. Immunol. 145:3002-3010.

34. Perlmutter, R.M., et al. 1984. The generation of diversity in phosphorylcholine-binding antibodies. Adv. Immunol. 35:1-37.

35. Potter, M. 1977. Antigen-binding myeloma proteins of mice. Adv. Immunol. 25:141-211.

36. Pennell, C.A., Arnold, L.W., Haughton, G., and Clarke, S.H. 1988. Restricted Ig variable region gene expression among $\mathrm{Ly}^{-1^{+}} \mathrm{B}$ cell lymphomas. J. Immunol. 141:2788-2796.

37. Hardy, R.R., Carmack, C.E., Li, Y.S., and Hayakawa, K. 1994. Distinctive developmental origins and specificities of murine $\mathrm{CD}^{+} \mathrm{B}$ cells. Immunol. Rev. 137:91-118.

38. Seidl, K.J., et al. 1997. Frequent occurrence of identical heavy and light chain Ig rearrangements. Int. Immunol. 9:689-702.

39. Insel, R.A., Adderson, E.E., and Carroll, W.L. 1992. The repertoire of human antibody to the Haemophilus influenzae type b capsular polysaccharide. Int. Rev. Immunol. 9:25-43.

40. Scott, M.G., Zachau, H.G., and Nahm, M.H. 1992. The human antibody $\mathrm{V}$ region repertoire to the type B capsular polysaccharide of Haemophilus influenzae. Int. Rev. Immunol. 9:45-55.
41. Lucas, A.H., Moulton, K.D., and Reason, D.C. 1998. Role of kappa II-A2 light chain CDR-3 junctional residues in human antibody binding to the Haemophilus influenzae type b polysaccharide. J. Immunol. 161:3776-3780.

42. Sun, Y., et al. 1999. Repertoire of human antibodies against the polysaccharide capsule of Streptococcus pneumoniae serotype 6B. Infect. Immun. 67:1172-1179.

43. Zhou, J., Lottenbach, K.R., Barenkamp, S.J., Lucas, A.H., and Reason, D.C. 2002. Recurrent variable region gene usage and somatic mutation in the human antibody response to the capsular polysaccharide of Streptococcus pneumoniae type 23F. Infect. Immun. 70:4083-4091.

44. Pascual, V., et al. 1992. $V_{H}$ restriction among human cold agglutinins. The $\mathrm{V}_{\mathrm{H}} 4-21$ gene segment is required to encode anti-I and anti-i specificities. J. Immunol. 149:2337-2344.

45. Thompson, K.M., et al. 1991. Human monoclonal antibodies against blood group antigens preferentially express a $V_{\mathrm{H}} 4-21$ variable region gene-associated epitope. Scand. J. Immunol. 34:509-518.

46. Silberstein, L.E., George, A., Durdik, J.M., and Kipps, T.J. 1996. The V4-34 encoded anti-i autoantibodies recognize a large subset of human and mouse B-cells. Blood Cells Mol. Dis. 22:126-138.

47. Silverman, G.J., et al. 1988. Idiotypic and subgroup analysis of human monoclonal rheumatoid factors. Implications for structural and genetic basis of autoantibodies in humans. J. Clin. Invest. 82:469-475.

48. Silverman, G.J., Schrohenloher, R.E., Accavitti, M.A., Koopman, W.J., and Carson, D.A. 1990. Structural characterization of the second major crossreactive idiotype group of human rheumatoid factors. Association with the $\mathrm{V}_{\mathrm{H}} 4$ gene family. Arthritis Rheum. 33:1347-1360.

49. Martin, T., et al. 2000. Salivary gland lymphomas in patients with Sjogren's syndrome may frequently develop from rheumatoid factor B cells. Arthritis Rheum. 43:908-916.

50. Mariette, X. 2001. Lymphomas complicating Sjogren's syndrome and hepatitis $\mathrm{C}$ virus infection may share a common pathogenesis: chronic stimulation of rheumatoid factor B cells. Ann. Rheum. Dis. 60:1007-1010

51. De Re, V., et al. 2002. Salivary gland B cell lymphoproliferative disorders in Sjogren's syndrome present a restricted use of antigen receptor gene segments similar to those used by hepatitis C virus-associated non-Hodgkin's lymphomas. Eur.J. Immunol. 32:903-910.

52. Milner, E.C., and Capra, J.D. 1982. $\mathrm{V}_{\mathrm{H}}$ families in the antibody response to $p$-azophenylarsonate: correlation between serology and amino acid sequence. J. Immunol. 129:193-199.

53. Jeske, D.J., Jarvis, J., Milstein, C., and Capra, J.D. 1984. Junctional diversity is essential to antibody activity. J. Immunol. 133:1090-1092.

54. Sanz, I., and Capra, J. 1987. VK and JK gene segments of A/J Ars-A antibodies: somatic recombination generates the essential arginine at the junction of the variable and joining regions. Proc. Natl. Acad. Sci. U. S. A. 84:1085-1089.

55. Casadevall, A., and Scharff, M.D. 1991. The mouse antibody response to infection with Cryptococcus neoformans: $\mathrm{V}_{\mathrm{H}}$ and $\mathrm{V}_{\mathrm{L}}$ usage in polysaccharide binding antibodies. J. Exp. Med. 174:151-160.

56. Scott, M.G., et al. 1989. Clonal characterization of the human IgG antibody repertoire to Haemophilus influenzae type b polysaccharide. III. A single VKII gene and one of several JK genes are joined by an invariant arginine to form the most common $\mathrm{L}$ chain V region. J. Immunol. 143:4110-4116.

57. Ibrahim, S.M., Weigert, M., Basu, C., Erikson, J., and Radic, M.Z. 1995. Light chain contribution to specificity in anti-DNA antibodies. J. Immunol. 155:3223-3233.
58. Radic, M.Z., et al. 1993. Residues that mediate DNA binding of autoimmune antibodies. J. Immunol. 150:4966-4977.

59. Rudikoff, S., Rao, D.N., Glaudemans, C.P., and Potter, M. 1980. kappa Chain joining segments and structural diversity of antibody combining sites. Proc. Natl. Acad. Sci. U. S. A. 77:4270-4274.

60. Chen, C., et al. 1994. Deletion and editing of B cells that express antibodies to DNA. J. Immunol. 152:1970-1982.

61. James, L.C., Roversi, P., and Tawfik, D.S. 2003. Antibody multispecificity mediated by conformational diversity. Science. 299:1362-1367.

62. Merlini, G., Farhangi, M., and Osserman, E.F. 1986. Monoclonal immunoglobulins with antibody activity in myeloma, macroglobulinemia and related plasma cell dyscrasias. Semin. Oncol. 13:350-365.

63. Azmi, F.H., Lucas, A.H., Spiegelberg, H.L., and Granoff, D.M. 1995. Human immunoglobulin M paraproteins cross-reactive with Neisseria meningitidis group B polysaccharide and fetal brain. Infect. Immun. 63:1906-1913.

64. Adderson, E.E., Shikhman, A.R., Ward, K.E., and Cunningham, M.W. 1998. Molecular analysis of polyreactive monoclonal antibodies from rheumatic carditis: human anti- $N$-acetylglucosamine/antimyosin antibody $\mathrm{V}$ region genes. J. Immunol. 161:2020-2031.

65. Diaw, L., et al. 1999. Restricted immunoglobulin variable region (Ig V) gene expression accompanies secondary rearrangements of light chain Ig V genes in mouse plasmacytomas. J. Exp. Med. 190:1405-1416.

66. Briles, D.E., et al. 1981. Antiphosphocholine antibodies found in normal mouse serum are protective against intravenous infection with type 3 streptococcus pneumoniae. J. Exp. Med. 153:694-705.

67. Ochsenbein, A.F., et al. 1999. Control of early viral and bacterial distribution and disease by natural antibodies. Science. 286:2156-2159.

68. Diamond, B., and Scharff, M.D. 1984. Somatic mutation of the T15 heavy chain gives rise to an antibody with autoantibody specificity. Proc. Natl. Acad. Sci. U. S. A. 81:5841-5844.

69. Sthoeger, Z.M., et al. 1989. Production of autoantibodies by CD5-expressing B lymphocytes from patients with chronic lymphocytic leukemia. J. Exp. Med. 169:255-268.

70. Borche, L., Lim, A., Binet, J.L., and Dighiero, G. 1990. Evidence that chronic lymphocytic leukemia B lymphocytes are frequently committed to production of natural autoantibodies. Blood. 76:562-569.

71. Wakai, M., et al. 1994. $\mathrm{IgG}^{+}, \mathrm{CD}^{+}$human chronic lymphocytic leukemia B cells. Production of IgG antibodies that exhibit diminished autoreactivity and IgG subclass skewing. Autoimmunity. 19:39-48.

72. Tobin, G., et al. 2002. Somatically mutated Ig $\mathrm{V}(\mathrm{H}) 3-21$ genes characterize a new subset of chronic lymphocytic leukemia. Blood. 99:2262-2264.

73. Tobin, G., et al. 2003. Chronic lymphocytic leukemias utilizing the VH3-21 gene display highly restricted V\{lambda\}2-14 gene use and homologous CDR3s: implicating recognition of a common antigen epitope. Blood. 101:4952-4957.

74. Martin, F., and Kearney, J.F. 2002. Marginal-zone B cells. Positive selection from newly formed to marginal zone B cells depends on the rate of clonal production, CD19, and btk. Nat. Rev. Immunol. 2:323-335.

75. Kuppers, R., and Dalla-Favera, R. 2001. Mechanisms of chromosomal translocations in B cell lymphomas. Oncogene. 20:5580-5594.

76. Weller, S., et al. 2001. CD40-CD40L independent Ig gene hypermutation suggests a second $\mathrm{B}$ cell diversification pathway in humans. Proc. Natl. Acad. Sci. U. S. A. 98:1166-1170.

77. William, J., Euler, C., Christensen, S., and Shlom- 
chik, M.J. 2002. Evolution of autoantibody responses via somatic hypermutation outside of germinal centers. Science. 297:2066-2070.

78. Chen, X., Martin, F., Forbush, K.A., Perlmutter, R.M., and Kearney, J.F. 1997. Evidence for selection of a population of multi-reactive $B$ cells into the splenic marginal zone. Int. Immunol. 9:27-41.

79. Bendelac, A., Bonneville, M., and Kearney, J.F. 2001. Autoreactivity by design: innate B and T lymphocytes. Nat. Rev. Immunol. 1:177-186.

80. Li, Y., Li, H., and Weigert, M. 2002. Autoreactive B cells in the marginal zone that express dual receptors. J. Exp. Med. 195:181-188.

81. Martin, F., and Kearney, J.F. 2000. Positive selection from newly formed to marginal zone B cells depends on the rate of clonal production, CD19, and btk. Immunity. 12:39-49.

82. Dammers, P.M., Visser, A., Popa, E.R., Nieuwenhuis, P., and Kroese, F.G. 2000. Most marginal zone B cells in rat express germline encoded $\mathrm{Ig} \mathrm{V}_{\mathrm{H}}$ genes and are ligand selected. J. Immunol. 165:6156-6169.

83. Damle, R.N., et al. 1999. Ig V gene mutation status and CD38 expression as novel prognostic indicators in chronic lymphocytic leukemia. Blood. 94:1840-1847.

84. Hamblin, T.J., Davis, Z., Gardiner, A., Oscier, D.G., and Stevenson, F.K. 1999. Unmutated $\operatorname{Ig} V_{H}$ genes are associated with a more aggressive form of chronic lymphocytic leukemia. Blood. 94:1848-1854.

85. Fu, S.M., Chiorazzi, N., Kunkel, H.G., Halper, J.P., and Harris, S.R. 1978. Induction of in vitro differen- tiation and immunoglobulin synthesis of human leukemic B lymphocytes. J. Exp. Med. 148:1570-1578.

86. Totterman, T.H., Nilsson, K., and Sundstrom, C. 1980. Phorbol ester-induced differentiation of chronic lymphocytic leukaemia cells. Nature. 288:176-178

87. Rubartelli, A., Sitia, R., Zicca, A., Grossi, C.E., and Ferrarini, M. 1983. Differentiation of chronic lymphocytic leukemia cells: correlation between the synthesis and secretion of immunoglobulins and the ultrastructure of the malignant cells. Blood. 62:495-504.

88. Gurrieri, C., et al. 2002. Chronic lymphocytic leukemia B cells undergo somatic hypermutation and intraclonal immunoglobulin $\mathrm{V}_{\mathrm{H}} \mathrm{DJ} \mathrm{H}_{\mathrm{H}}$ gene diversification. J. Exp. Med. 196:629-639.

89. Zupo, S., et al. 1996. CD38 expression distinguishes two groups of B-cell chronic lymphocytic leukemias with different responses to anti-IgM antibodies and propensity to apoptosis. Blood. 88: $1365-1374$

90. Lanham, S., et al. 2003. Differential signaling via surface $\operatorname{IgM}$ is associated with $V_{\mathrm{H}}$ gene mutational status and CD38 expression in chronic lymphocytic leukemia. Blood. 101:1087-1093.

91. Kraulis, P.J. 1991. MOLSCRIPT: a program to produce both detailed and schematic plots of protein structures. J. Appl. Crystallogr. 24:946-950.

92. Merritt, E.A., and Murphy, M.E.P. 1994. Raster3D Version 2.0: a program for photorealistic molecular graphics. Acta Crystallogr. D. 50:869-873.
93. Nicholls, A., Sharp, K.A., and Honig, B. 1991. Protein folding and association: insights from the interfacial and thermodynamic properties of hydrocarbons. Proteins. 11:281-296.

94. Klein, R., Jaenichen, R., and Zachau, H.G. 1993. Expressed human immunoglobulin kappa genes and their hypermutation. Eur. J. Immunol. 23:3248-3262.

95. Graille, M., et al. 2001. Complex between Peptostreptococcus magnus protein $\mathrm{L}$ and a human antibody reveals structural convergence in the interaction modes of Fab binding proteins. Structure. 9:679-687.

96. Jacobin, M.J., et al. 2002. Human IgG monoclonal anti-alpha(IIb)beta(3)-binding fragments derived from immunized donors using phage display. J. Immunol. 168:2035-2045.

97. de Wildt, R.M., Hoet, R.M.A., van Venrooij, W.J., Tomlinson, I.M., and Winter, G. 1999. Analysis of heavy and light chain pairings indicates that receptor editing shapes the human antibody repertoire. J. Mol. Biol. 285:895-901.

98. Brown, C.M., Plater-Zyberk, C., Mageed, R.A., Jefferis, R., and Maini, R.N. 1990. Analysis of immunoglobulins secreted by hybridomas derived from rheumatoid synovia. Clin. Exp. Immunol. 80:366-372.

99. Chang, T.Y., and Siegel, D.L. 1998. Genetic and immunological properties of phage-displayed human anti-Rh(D) antibodies: implications for Rh(D) epitope topology. Blood. 91:3066-3078. 